\title{
Does the acanthocephalan parasite Polymorphus minutus modify the energy reserves and antitoxic defences of its intermediate host Gammarus roeseli?
}

\author{
E. GISMONDI*, C. COSSU-LEGUILLE and J.-N. BEISEL \\ Laboratoire des Interactions Ecotoxicologie Biodiversité Ecosystèmes (LIEBE) - CNRS UMR 7146, Université de Lorraine \\ (UdL), Campus Bridoux, Bât. IBiSE, 8 Rue du Général Delestraint, 57070 Metz, France
}

(Received 27 October 2011; revised 15 December 2011 and 1 February 2012; accepted 1 February 2012)

\begin{abstract}
SUMMARY
In disturbed environments, infected organisms have to face both parasitic and chemical stresses. Although this situation is common, few studies have been devoted to the effects of infection on hosts' energy reserves and antitoxic defence capacities, while parasite survival depends on host survival. In this study, we tested the consequences of an infection by Polymorphus minutus on the energy reserves (protein, lipid and glycogen) and antioxidant defence capacities (reduced glutathione, $\gamma$-glutamylcysteine ligase activity) of Gammarus roeseli males and females, in the absence of chemical stress. Moreover, malondialdehyde concentration was used as a toxicity biomarker. The results revealed that in infected $G$. roeseli, whatever their gender and the sampling month, protein and lipid contents were lower, but glycogen contents were higher. This could be explained by the fact that the parasite diverts part of the host's energy for its own development. Moreover, glutathione concentrations and $\gamma$-glutamylcysteine ligase activity were both lower, which could lead to lower antitoxic defence in the host. These results suggest negative effects on individuals in the case of additional stress (e.g. pollutant exposure). In the absence of chemical stress, the lower malondialdehyde level in infected gammarids could imply a probable protective effect of the parasite.
\end{abstract}

Key words: acanthocephalan, cystacanth stage, amphipod, energy reserves, antitoxic defences, glutathione, malondialdehyde.

\section{INTRODUCTION}

Among the numerous parasite species known to alter the phenotype of their intermediate hosts, acanthocephalan parasites have been shown to manipulate the behaviour of their intermediate arthropod host to make it more prone to predation by their final vertebrate host (Poulin, 1995; Lafferty, 1999; Kennedy, 2006). The behavioural changes induced by acanthocephalans can vary and include reaction to light (Bauer et al. 2000; Cézilly et al. 2000; PerrotMinnot, 2004), vertical distribution (Cézilly et al. 2000; Bauer et al. 2005; Médoc et al. 2006), drift behaviour (McCahon et al. 1991; Maynard et al. 1998), activity level (Dezfuli et al. 2003) or the refuge use and the escape performance faced with non-host predators (Baldauf et al. 2007; Perrot-Minnot et al. 2007; Médoc and Beisel, 2009; Médoc et al. 2009; Beisel and Médoc, 2010). Behavioural changes make gammarids more likely to be preyed upon by the parasite's final host (Lagrue et al. 2007;

* Corresponding author: Laboratoire des Interactions Ecotoxicologie Biodiversité Ecosystèmes (LIEBE)CNRS UMR 7146, Université de Lorraine (UdL), Campus Bridoux, Bât. IBiSE, 8 Rue du Général Delestraint, 57070 Metz, France. Tel: +33(0)387378500. Fax: +33(0)387378512. E-mail: eric.gismondi@hotmail.fr
Perrot-Minnot et al. 2007; Cézilly et al. 2010). Although much attention has been focused on behavioural changes, few studies have been devoted to the physiological consequences of acanthocephalan infection in the intermediate host. For example, Cornet et al. (2009) described that acanthocephalans reduced the immune capacity of Gammarus pulex. In addition, parasites need their host to survive both in terms of energy supply for their own development and of their transmission to a final host (Plaistow et al. 2001). In disturbed environments, antitoxic defence capacities may play a keyrole to allow the survival of the intermediate host faced with biotic (parasites) and abiotic (pollutants) stresses. A conflict between these two factors may occur and compromise the future of infected individuals. The parasite could also protect the host from a pollutant, as sometimes demonstrated for adult acanthocephalans in their fish hosts (Sures and Siddall, 1999; Sures et al. 2003).

Gammarus roeseli is a widespread amphipod crustacean of Balkan-European origin (Jazdzewski, 1980; Barnard and Barnard, 1983), often used as a biological model in ecotoxicological studies that aim at developing biomarkers, especially antitoxic defence system biomarkers (Sroda and Cossu-Leguille, $2011 a, b)$. In natural populations, $G$. roeseli 
commonly serves as an intermediate host for numerous acanthocephalan parasites, including the water bird acanthocephalan Polymorphus minutus (Médoc and Beisel, 2009). G. roeseli get infected as a result of eating $P$. minutus eggs released in the final host's feces. They hatch in the intestine and release acanthor which move into the haemocoel, where they develop into cystacanths (infective larvae). This larval stage is characterized by an orange carotenoid-based colour which makes it visible through the translucent cuticle of infested gammarids (Kennedy, 2006).

The aim of our study was to investigate the influence of $P$. minutus on the energy reserves and antitoxic defence capacities of its intermediate host $G$. roeseli in May, June and August, which correspond to the period of high prevalence in our study site (Médoc and Beisel, 2009). As parasite survival and transmission depend on host survival, we hypothesized that $P$. minutus could protect its host. We therefore assumed that $P$. minutus-infected gammarids could have higher defence capacities (higher GSH concentrations) as well as lower cell damage (lower MDA levels) as compared to uninfected ones. Energy reserves were assessed by assaying protein concentrations as well as total lipid and glycogen contents. Glycogen levels are representative of the energy available for current activities (Sparkes et al. 1996) whereas lipids are stored in fat bodies and serve as nutrients used during starvation or reproduction periods (Cargill et al. 1985). Antitoxic defences were estimated by measuring reduced glutathione ( $\mathrm{GSH}$ ) concentrations. GSH is a tripeptide whose role is essential in the detoxification system thanks to its thiol function, and its action as a scavenger of organic or metal xenobiotics (Griffith, 1999; Vasseur and Leguille, 2004). GSH is commonly used in ecotoxicology studies on invertebrates; its concentration may be reduced in organisms exposed to copper (Doyotte et al. 1997; Canesi et al. 1999) or lead (Yan et al. 1997). It also plays an important role as a substrate for several antioxidant enzymes like seleniumdependent glutathione peroxidase (SeGPx, EC 1.11.1.9) or glutathione-S-tranferases. The activity of $\gamma$-glutamylcysteine ligase (GCL, EC 6.3.2.2), the enzyme that limits de novo synthesis of glutathione, was measured in parallel to glutathione concentrations. Finally, we measured the level of malondialdehyde (MDA), which is a product of lipid peroxidation reflecting cellular damage (Correia et al. 2002; Neuparth et al. 2005). This toxicity biomarker enables us to assess the probable protective effect of the parasite on its host: lower MDA levels reflect lower cell damage. In this study, we also hypothesized that gender could have an influence on biomarker variation, as shown by Sroda and CossuLeguille $(2011 a, b)$, on antioxidant enzyme activities; therefore measurements were performed separately on males and females.
MATERIALS AND METHODS

\section{Gammarus roeseli sampling}

Male and female $G$. roeseli were collected using hand nets and artificial traps in the Nied River (Laquenexy, North-eastern France, $49^{\circ} 05^{\prime} \mathrm{N}$ and $6^{\circ} 19^{\prime} \mathrm{E}$ ) in May, June and August 2009. The low number of infected gammarids in July did not allow us to perform any comparisons. Infected $G$. roeseli were easily identified as the parasite appears as an intense orange dot through the cuticle. Dissection was performed to confirm infection by $P$. minutus. According to a previous study, the overall prevalence of $P$. minutus varied over the sampling period, ranging from 0.08 in May and October to 0.13 in August (Médoc and Beisel, 2009). Male and female gammarids were sorted on the spot according to gnathopod size, a sexual dimorphism character. The animals were immediately transported to the laboratory in river water, where they were frozen in liquid nitrogen and stored at $-80^{\circ} \mathrm{C}$. Four pools of 7 males and 4 pools of 10 non-gravid females were prepared for each analysis. Prior to analyses, $G$. roeseli gender was checked by observing genital papillae (found in males only) on the 7 th ventral segment. Two conditions were studied: (i) uninfected gammarids corresponding to controls, and (ii) infected gammarids out of which the parasite was removed by dissection.

\section{Sample preparation}

Each pool was homogenized with a manual Potter Elvejhem tissue grinder in a $50 \mathrm{mM}$ phosphate buffer $\mathrm{KH}_{2} \mathrm{PO}_{4} / \mathrm{K}_{2} \mathrm{HPO}_{4} \quad(\mathrm{pH} \quad 7 \cdot 6)$ supplemented with $1 \mathrm{mM}$ phenylmethylsulphonylfluoride (PMSF) and $1 \mathrm{mM}$ L-serine-borate mixture as protease inhibitors and $5 \mathrm{mM}$ phenylglyoxal as a $\gamma$-glutamyl transpeptidase inhibitor. The homogenization buffer was adjusted at a volume 2 -fold the wet weight of the sample pool (e.g. $400 \mu$ l of homogenization buffer for $200 \mathrm{mg}$ of wet weight tissue). All homogenates were used for the assays immediately after being prepared. The homogenate was divided into 5 parts to measure the different parameters. For each replicate, 2 independent measures were performed for each biomarker. Then, the average of the 2 independent measures was estimated.

\section{Lipid and glycogen assays}

The measurement of total lipid and glycogen contents was adapted from Plaistow et al . (2001). Twenty microlitres of $2 \%$ sodium sulphate (w/v) and $540 \mu \mathrm{l}$ of chloroform/methanol 1:2(v/v) were added to $40 \mu \mathrm{l}$ of total homogenate. After $1 \mathrm{~h}$ on ice, the samples were centrifuged at $3000 \mathrm{~g}$ for $5 \mathrm{~min}$ at $4{ }^{\circ} \mathrm{C}$. The resulting supernatant and the pellet were used to determine the total lipid and glycogen contents, respectively. 
Samples of $100 \mu \mathrm{l}$ of the supernatant were transferred to culture tubes and placed in a dry bath at $95{ }^{\circ} \mathrm{C}$ to evaporate the solvent. Then, $200 \mu \mathrm{l}$ of $95 \%$ sulphuric acid were added in each tube and left for $10 \mathrm{~min}$. The culture tubes were cooled on ice and $4.8 \mathrm{ml}$ of a vanillin-phosphoric acid reagent, composed of $120 \mathrm{mg}$ of vanillin, $20 \mathrm{ml}$ of ultrapure ethanol $(95 \%)$ and $80 \mathrm{ml}$ of phosphoric acid (85\%), were added. After a $10-$ min reaction time, optical density was measured at $535 \mathrm{~nm}$. Commercial cholesterol was used as a standard and lipid contents were expressed in $\mathrm{mg} \cdot \mathrm{ml}^{-1}$.

Total dissolution of the pellet was performed in $400 \mu \mathrm{l}$ of deionized (milliQ) water for $10 \mathrm{~min}$ in an ultrasonic bath, and $100 \mu \mathrm{l}$ of sample were placed in culture tubes and $4.9 \mathrm{ml}$ of anthrone reagent were added. The anthrone reagent is a mixture of $1.13 \mathrm{~g}$ of anthrone, $170 \mathrm{ml}$ of ultrapure water and $630 \mathrm{ml}$ of sulphuric acid $(95 \%)$. The mixture was placed in a dry bath at $95^{\circ} \mathrm{C}$ for $17 \mathrm{~min}$ and then cooled on ice. Optical density was measured at $625 \mathrm{~nm}$. Glucose was used as a standard and concentrations were expressed in $\mu \mathrm{g} \cdot \mathrm{mg}^{-1}$ tissue.

\section{Total protein assay}

The total protein content of each sample was quantified according to the method of Bradford (1976) with bovine serum albumin (BSA) as a standard. The results were expressed in mg. $\mathrm{ml}^{-1}$.

\section{Reduced glutathione assay}

Reduced glutathione (GSH) concentration measurement was adapted from Leroy et al. (1993) using High-Pressure Liquid Chromatography (HPLC) separation, which consisted in a post-column derivatization with ortho-phtaldialdehyde solution and fluorimetric detection at $340 \mathrm{~nm}$ excitation and $440 \mathrm{~nm}$ emission wavelengths. The proteins from $40 \mu \mathrm{l}$ of the total homogenate were precipitated with $10 \%$ perchloric acid $(\mathrm{v} / \mathrm{v})$. After centrifugation for $10 \mathrm{~min}$ at $20000 \mathrm{~g}$ at $4{ }^{\circ} \mathrm{C}$, the resulting supernatant was diluted 40 -fold in $0 \cdot 1 \mathrm{M}$ hydrochloric acid $(\mathrm{HCl})$. Then $20 \mu 1$ of the diluted supernatant were injected in a reverse-phase LiChrospher 100 RP18-encapped column $(125 \mathrm{~mm} \times 4 \mathrm{~mm}, 5 \mu \mathrm{m})$ and separation was carried out at $25{ }^{\circ} \mathrm{C}$. Elution was performed with $7 \%$ acetonitrile (Chromanorm, 95\%) in a $0.01 \mathrm{M}$ phosphate buffer $\mathrm{KH}_{2} \mathrm{PO}_{4} / \mathrm{Na}_{2}$ EDTA ( $\mathrm{pH} 2 \cdot 50$ ) containing $0.5 \mathrm{mM} n$-decylsodiumsulfate as an ion-pairing reagent. Commercial GSH diluted in $0 \cdot 1 \mathrm{M} \mathrm{HCl}$ was used as a standard and GSH concentrations were expressed in nmol GSH.mg ${ }^{-1}$ protein.

\section{Enzymatic assay}

The activity of $\gamma$-glutamylcysteine ligase (GCL) was assayed using an HPLC method adapted from
Parmentier et al. (1998). Measurements were carried out on the S12000 fraction obtained after centrifuging $40 \mu \mathrm{l}$ of the total homogenate for $15 \mathrm{~min}$ at $500 \mathrm{~g}$ and then centrifuging the resulting supernatant at $12000 \mathrm{~g}$ and $4{ }^{\circ} \mathrm{C}$ for $30 \mathrm{~min}$. The resulting $\mathrm{S} 12000$ fraction was diluted 20 -fold in the homogenization buffer and $40 \mu \mathrm{l}$ of this diluted solution were added to $112 \mu \mathrm{l}$ of incubation cocktail $(0.5 \mathrm{M}$ Tris- $\mathrm{HCl}$, $200 \mathrm{mM} \mathrm{MgCl}_{2} 6 \mathrm{H}_{2} \mathrm{O}, 500 \mathrm{mM} \mathrm{KCl}, 45 \mathrm{mM}$ glutamic acid, $90 \mathrm{mM}$ cystein, $1 \mathrm{mM}$ DTT, $90 \mathrm{mM}$ ATP, $0.5 \mathrm{mM}$ phénylglyoxal, $\mathrm{pH} 8.25$ ) in a $1.5 \mathrm{ml}$ tube to initiate the reaction. After a 20-min incubation period at $25^{\circ} \mathrm{C}$, the reaction was stopped by a 4 -fold dilution with $0 \cdot 1 \mathrm{M} \mathrm{HCl}$ and $20 \mu \mathrm{l}$ of the resulting solution were injected into a LiChrospher 100 RP18-encapped HPLC column $(125 \mathrm{~mm} \times 4 \mathrm{~mm}, 5 \mu \mathrm{m})$. Commercial glutamylcysteine (GC) solution was used as a standard and GCL activity was expressed in nmol GC.min ${ }^{-1} \cdot \mathrm{mg}^{-1}$ protein.

\section{Lipoperoxidation}

Malondialdehyde (MDA) levels were measured with an HPLC method adapted from Behrens and Madère (1991) with UV detection at $267 \mathrm{~nm}$. Seventy microlitres of the total homogenate were diluted 4 -fold in 95\% ethanol (HPLC grade) and cooled on ice for $1.5 \mathrm{~h}$ to de-proteinize them. The mixture was then centrifuged at $18000 \mathrm{~g}$ for $30 \mathrm{~min}$ at $4{ }^{\circ} \mathrm{C}$ and $100 \mu \mathrm{l}$ of the resulting supernatant were injected directly into a reserved-phase LiChrospher 100RP18-encapped HPLC column. Separation was performed at $25^{\circ} \mathrm{C}$ and elution was carried out with sodium phosphate buffer ( $\mathrm{pH} 6 \cdot 5)$ containing 25\% ethanol and $0.5 \mathrm{mM}$ tetradecylmethylammoniun bromide as an ion-paring reagent. MDA levels were expressed in ng MDA.mg ${ }^{-1}$ lipid.

\section{Statistical analyses}

Data analysis was performed using a multivariate analysis of variance (MANOVA, Pillai's trace) with respect to 'gender', 'infection status' and 'sampling month' as fixed factors. All data met normality and homogeneity of variance assumptions. MDA levels were not included in this analysis because the low number of infected gammarids in August did not allow us to measure them. As the MANOVA test was significant, each biomarker was then analysed using the ANOVA test, followed by the TukeyHSD posthoc test. All tests were performed with a 5\% type I error risk, using R 2.9.0 Software.

\section{RESULTS}

\section{Acanthocephalan effect on $\mathrm{G}$. roeseli biomarker}

Global MANOVA and ANOVA analysis revealed an effect of the sampling month, of individual gender, of 
Table 1. Multivariate analyses of variance (Pillai's trace) investigating variations in energy reserves (protein, lipid, glycogen) and defence capacity (GSH, GCL) of Gammarus roeseli, as a function of infection by acanthocephalan parasites, month sampling and individual gender

\begin{tabular}{lcrc}
\hline \hline Source of variation & num D.F ${ }^{\text {a }}$ den D.F. & F & $P$ value \\
\hline Whole model & 55,180 & $18 \cdot 94$ & $<0 \cdot 0001$ \\
Month & 5,36 & $41 \cdot 75$ & $<0 \cdot 0001$ \\
Gender & 5,36 & $30 \cdot 10$ & $<0 \cdot 0001$ \\
Infection status & 5,36 & $102 \cdot 27$ & $<0 \cdot 0001$ \\
Month $\times$ Gender & 5,36 & $10 \cdot 57$ & $<0 \cdot 0001$ \\
Month $\times$ Infection status & 5,36 & $10 \cdot 33$ & $<0 \cdot 0001$ \\
Gender $\times$ Infection status & 5,36 & $6 \cdot 37$ & $0 \cdot 0002$ \\
Month $\times$ Gender $\times$ Infection status & 5,36 & $5 \cdot 83$ & $0 \cdot 0004$ \\
\hline \hline
\end{tabular}

${ }^{a}$ Numerator degrees of freedom. ${ }^{b}$ Denominator degrees of freedom.

parasite infection and of their interactions on the variations of biomarker levels (Tables 1 and 2). The results are detailed below for each biomarker category.

\section{Parasitism and energy reserves}

Energy reserves (protein, lipid and glycogen) were influenced by $P$. minutus infection, gender and sampling month (Table 2). Gammarid protein concentrations were lower in the presence of $P$. minutus in the two genders whatever the sampling month (Fig. 1A). Moreover, no significant monthly variations were observed in uninfected and infected males and females. The same trend was observed for total lipid contents, which were lower in the presence of $P$. minutus in the two genders at each sampling month, except for males in August (Fig. 1B). Total lipid contents in infected females were on average $1 \cdot 5$-fold lower as compared to uninfected ones; while in infected males, they were on average $1 \cdot 2$-fold lower than in uninfected ones. Comparison of males and females showed that lipid contents were higher in uninfected females than in uninfected males whatever the sampling month, whereas there was no significant difference between infected males and females. In males, monthly variations of total lipid contents were observed only in uninfected individuals, whereas in females, these variations were marked whatever the infection status (Fig. 1B).

Conversely, the presence of the acanthocephalan $P$. minutus increased glycogen contents whatever the gender and the sampling month, except for females in May (Fig. 1C). In infected males, the glycogen contents were $1 \cdot 7$-fold higher as compared to uninfected ones, whereas in infected females they were $2 \cdot 4$-fold higher as compared to uninfected ones. The differences in glycogen contents were highest in August in both genders. Indeed during that month, glycogen contents in infected males were $1 \cdot 5$-fold higher than in uninfected ones and were 3 -fold higher in infected females as compared to uninfected ones. Unlike in uninfected males and females, no significant difference in glycogen contents was observed between infected males and females depending on the sampling month, except in June.

\section{Parasitism and antitoxic defences}

$P$. minutus has an influence on the defence capacities of $G$. roeseli by decreasing GSH concentrations in both genders whatever the sampling month (Fig. 2A). Indeed, infected males and females displayed on average $1 \cdot 5-$ to $2 \cdot 5$-fold less GSH than uninfected ones, whatever the sampling month. The same variation in GSH concentration was observed in uninfected and infected individuals, whatever the gender and the sampling month. The decrease in GSH concentrations could be linked with the decrease in GCL activity, which was also marked in infected males and females (Fig. 2B). GCL activity was on average 2-fold lower in infected gammarids, whatever their gender and the sampling month. No significant difference was observed between males and females each month, whatever the infection status.

\section{Parasitism and toxic effect biomarker}

MDA levels were not measured in August due to the lack of infected $G$. roeseli, which led to a low total homogenate quantity. Univariate analysis of MDA levels revealed an effect of the presence of $P$. minutus (Table 2). MDA levels were lower in infected gammarids as compared to uninfected ones, whatever their gender and the sampling month (Table 3). Indeed, MDA levels were 1.5-fold lower in infected males and females than in uninfected ones. In addition, MDA levels were $1 \cdot 5$-fold higher in males than in females, whatever the infection status. Monthly variations were observed in uninfected and infected gammarids whatever the gender.

\section{DISCUSSION}

This study was carried out (i) to improve knowledge about the physiological effects of the acanthocephalan 
Table 2. Univariate analyses of variance (ANOVA) investigating variations in energy reserves (protein, lipid, and glycogen), in defence capacity (GSH, GCL) and the variation of a toxicity biomarker (MDA), in Gammarus roeseli, according to sampling month, gender and infection by Polymorphus minutus

\begin{tabular}{|c|c|c|c|c|c|}
\hline & & D.F. & Mean square & $\mathrm{F}$ & $P$ value \\
\hline \multirow{7}{*}{ Protein } & Month & 2 & $4 \cdot 96$ & $6 \cdot 52$ & $0 \cdot 004$ \\
\hline & Gender & 1 & $59 \cdot 05$ & $77 \cdot 61$ & $<0 \cdot 001$ \\
\hline & Parasite & 1 & $117 \cdot 09$ & $156 \cdot 49$ & $<0 \cdot 001$ \\
\hline & Month:Gender & 2 & $4 \cdot 8$ & $6 \cdot 30$ & 0.004 \\
\hline & Month:Parasite & 2 & $1 \cdot 46$ & $1 \cdot 91$ & $0 \cdot 162$ \\
\hline & Gender:Parasite & 1 & $0 \cdot 28$ & $0 \cdot 37$ & $0 \cdot 548$ \\
\hline & Gender:Parasite:Month & 2 & $12 \cdot 76$ & $16 \cdot 76$ & $<0 \cdot 001$ \\
\hline \multirow[t]{7}{*}{ Lipid } & Month & 2 & $9 \cdot 31$ & $64 \cdot 76$ & $<0 \cdot 001$ \\
\hline & Gender & 1 & 33.99 & $236 \cdot 4$ & $<0 \cdot 001$ \\
\hline & Parasite & 1 & $14 \cdot 98$ & $104 \cdot 16$ & $<0 \cdot 001$ \\
\hline & Month:Gender & 2 & 1.99 & $13 \cdot 81$ & $<0.001$ \\
\hline & Month:Parasite & 2 & $1 \cdot 1$ & $7 \cdot 67$ & $0 \cdot 001$ \\
\hline & Gender:Parasite & 1 & $7 \cdot 8$ & $54 \cdot 26$ & $<0.001$ \\
\hline & Gender:Parasite:Month & 2 & $0 \cdot 06$ & $0 \cdot 40$ & $0 \cdot 671$ \\
\hline \multirow[t]{7}{*}{ Glycogen } & Month & 2 & $14 \cdot 73$ & $25 \cdot 42$ & $<0 \cdot 001$ \\
\hline & Gender & 1 & $10 \cdot 38$ & $17 \cdot 91$ & $<0 \cdot 001$ \\
\hline & Parasite & 1 & $28 \cdot 52$ & $49 \cdot 23$ & $<0 \cdot 001$ \\
\hline & Month:Gender & 2 & $5 \cdot 12$ & $8 \cdot 84$ & $<0.001$ \\
\hline & Month:Parasite & 2 & $23 \cdot 89$ & $41 \cdot 23$ & $<0 \cdot 001$ \\
\hline & Gender:Parasite & 1 & $6 \cdot 87$ & $11 \cdot 86$ & $0 \cdot 001$ \\
\hline & Gender:Parasite:Month & 2 & $0 \cdot 52$ & $0 \cdot 9$ & $0 \cdot 417$ \\
\hline \multirow[t]{7}{*}{ GSH } & Month & 2 & $4 \cdot 06$ & $93 \cdot 26$ & $<0 \cdot 001$ \\
\hline & Gender & 1 & $0 \cdot 51$ & $11 \cdot 64$ & $0 \cdot 001$ \\
\hline & Parasite & 1 & $4 \cdot 81$ & $110 \cdot 46$ & $<0.001$ \\
\hline & Month:Gender & 2 & $1 \cdot 47$ & $33 \cdot 82$ & $<0 \cdot 001$ \\
\hline & Month:Parasite & 2 & $0 \cdot 11$ & $2 \cdot 63$ & $0 \cdot 086$ \\
\hline & Gender:Parasite & 1 & $0 \cdot 04$ & $0 \cdot 82$ & $0 \cdot 371$ \\
\hline & Gender:Parasite:Month & 2 & $0 \cdot 13$ & $2 \cdot 91$ & $0 \cdot 067$ \\
\hline \multirow[t]{7}{*}{ GCL } & Month & 2 & $0 \cdot 2440$ & $67 \cdot 61$ & $<0.001$ \\
\hline & Gender & 1 & $0 \cdot 0010$ & $0 \cdot 19$ & 0.668 \\
\hline & Parasite & 1 & $0 \cdot 2000$ & $55 \cdot 44$ & $<0 \cdot 001$ \\
\hline & Month:Gender & 2 & $0 \cdot 0260$ & $7 \cdot 12$ & $0 \cdot 002$ \\
\hline & Month:Parasite & 2 & $0 \cdot 0240$ & $6 \cdot 75$ & $0 \cdot 003$ \\
\hline & Gender:Parasite & 1 & $0 \cdot 0001$ & $0 \cdot 04$ & $0 \cdot 849$ \\
\hline & Gender:Parasite:Month & 2 & $0 \cdot 0060$ & $1 \cdot 62$ & $0 \cdot 211$ \\
\hline \multirow[t]{7}{*}{ MDA } & Month & 1 & $87 \cdot 09$ & $244 \cdot 33$ & $<0 \cdot 001$ \\
\hline & Gender & 1 & $12 \cdot 97$ & $36 \cdot 38$ & $<0 \cdot 001$ \\
\hline & Parasite & 1 & $38 \cdot 70$ & $108 \cdot 57$ & $<0 \cdot 001$ \\
\hline & Month:Gender & 1 & $0 \cdot 18$ & $0 \cdot 49$ & $0 \cdot 489$ \\
\hline & Month:Parasite & 1 & $0 \cdot 51$ & $1 \cdot 44$ & $0 \cdot 242$ \\
\hline & Gender:Parasite & 1 & $0 \cdot 01$ & $0 \cdot 01$ & $0 \cdot 904$ \\
\hline & Gender:Parasite:Month & 1 & $1 \cdot 58$ & $4 \cdot 43$ & $0 \cdot 046$ \\
\hline
\end{tabular}

parasite Polymorphus minutus on its intermediate host Gammarus roeseli, especially on its energy reserves, and (ii) to assess the potential of infected individuals to deal with chemical stress by measuring defence capacities.

The presence of $P$. minutus in $G$. roeseli clearly influenced the energy reserves of its host by decreasing protein and total lipid concentrations and increasing glycogen contents in both genders. Plaistow et al. (2001) demonstrated that the acanthocephalan parasite $P$. laevis decreased total lipid content in infected $G$. pulex gravid females, but did not observe any difference in males depending on the infection status. Additionally, they also observed an increase in glycogen content in $P$. laevis-infected
G. pulex whatever the gender. However, Médoc et al. (2011) showed no difference in neutral lipid contents in $P$. minutus-infected $G$. roeseli as compared to uninfected ones. While a decrease in total lipid content in infected individuals has already been observed, the results obtained for glycogen content are rather more contrasting. Some studies highlighted an increase ( $P$. laevis in $G$. pulex-Plaistow et al. 2001) as in our study, or an absence of modification ( $P$. ringueletti-Isopoda ectoparasitein $P$. argentinus - Neves et al. 2004); but no one reported a glycogen decrease in an acanthocephalaninfected host although such a decrease was observed in other host-parasite systems as in Norway lobsters Nephrops norvegicus infected by the dinoflagellate 
Table 3. MDA levels depending on sampling period, Gammarus roeseli gender and infection status

( $P$ values highlight significant differences depending on the infection status and asterisks indicate seasonal variation.)

\begin{tabular}{|c|c|c|c|c|c|c|}
\hline & \multicolumn{3}{|l|}{ Males } & \multicolumn{3}{|l|}{ Females } \\
\hline & Uninfected & Infected & $P$ values & Uninfected & Infected & $P$ values \\
\hline May & $5 \cdot 47 \pm 0 \cdot 47 *$ & $3 \cdot 11 \pm 0 \cdot 70 *$ & $0 \cdot 00216$ & $3 \cdot 63 \pm 0 \cdot 60 *$ & $2 \cdot 10 \pm 0 \cdot 33^{*}$ & $0 \cdot 00754$ \\
\hline June & $8 \cdot 43 \pm 0 \cdot 58 *$ & $6 \cdot 45 \pm 0 \cdot 52^{*}$ & $0 \cdot 00227$ & $7 \cdot 78 \pm 0 \cdot 85^{*}$ & $4 \cdot 85 \pm 0.59 *$ & $0 \cdot 00193$ \\
\hline August & nd & nd & nd & nd & nd & nd \\
\hline
\end{tabular}

nd, not determined.

A

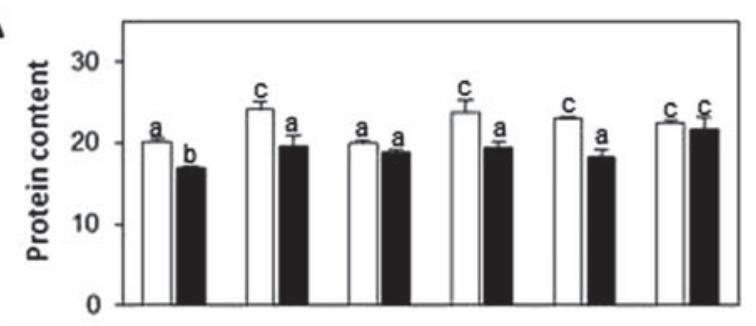

B

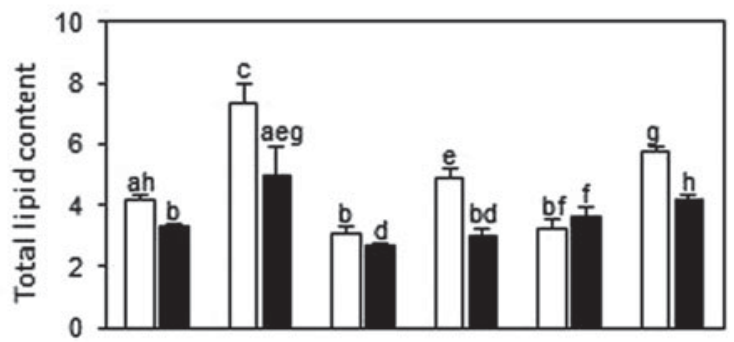

C

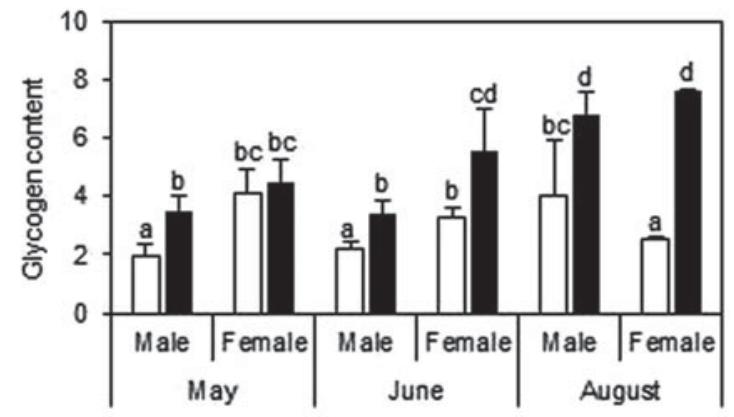

Fig. 1. Protein concentrations (A), total lipid (B) and glycogen contents $(\mathrm{C})$ depending on sampling period, Gammarus roeseli gender and infection status. Different letters above the bars indicate significantly different values (Tukey's HSD test, $P$ values $<0 \cdot 05$ ). White bars represent uninfected $G$. roeseli and black bars represent infected $G$. roeseli.

Hematodinium sp. (Stentiford et al. 2001). Our study underlined higher glycogen contents in P. minutusinfected $G$. roeseli as compared to uninfected ones, whatever the gender. We can hypothesize that the higher glycogen content in infected gammarids could be due to their immobility, since $P$. minutus-infected gammarids are known to stay at the water surface where they become more vulnerable to final host predation (Bakker et al. 1997; Bauer et al. 2000, 2005; Cézilly and Perrot-Minnot, 2005; Médoc et al.2006).
A

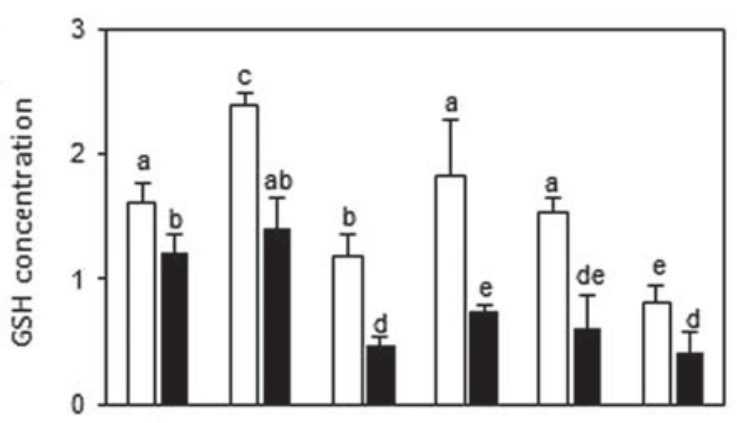

B

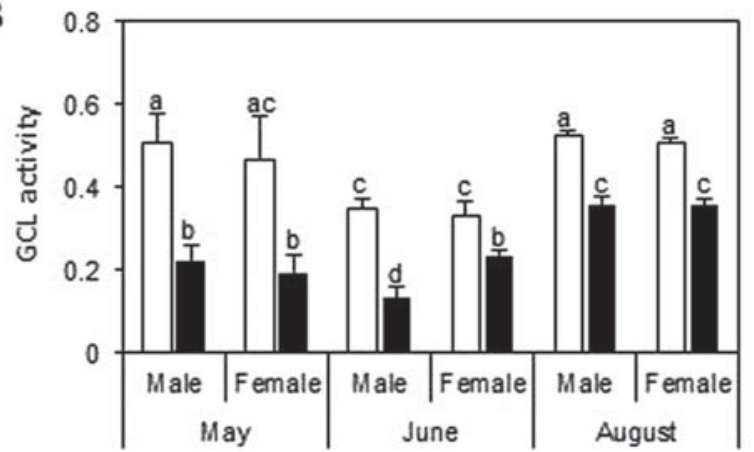

Fig. 2. GSH concentration (A) and GCL activity (B) depending on sampling month, Gammarus roeseli gender and infection status. Different letters above the bars indicate significantly different values (Tukey's HSD test, $P$ values $<0 \cdot 05)$. White bars represent uninfected $G$. roeseli and black bars represent infected $G$. roeseli.

It could also be due to a feeding rate increase as described in G. pulex infected by Echinorhynchus truttae (Dick et al. 2010) but another study showed that $P$. minutus-infected $G$. roeseli consumed as many dead isopods, but fewer living isopods and less leaf material as compared to uninfected ones (Médoc et al. 2011). We can also hypothesize that glycogen could be stored by gammarids as an alternative energy source because lipids are partly used by $P$. minutus.

The decrease in total lipid contents measured in our study could be due to the parasite's development. It is well known that parasites need energy for their own development inside their hosts, as demonstrated for P. minutus, which must store up host nutriments to attain the last larval stage (Crompton and Nickol, 1985; Taraschewski, 2000). So, the reduction of total 
lipid contents in infected $G$. roeseli could be explained by their consumption by P. minutus by osmotrophy. This hypothesis is supported by the study of Barrett and Butterworth (1968) who demonstrated that $P$. minutus gets its carotenoids from its host. Carotenoids, which are lipid constituents, are the main compound of the crustacean vitellus (Mantiri et al. 1996). Polymorphus minutus diverts carotenoids for its own development and consequently $G$. roeseli females become castrated (Bollache et al. 2002).

Polymorphus minutus decreased $G$. roeseli defence capacities: whatever the gender, a drop in reduced glutathione concentrations linked with a decrease in GCL activity was observed in P. minutus-infected $G$. roeseli as compared to uninfected ones. Several studies of gammarids infected by an acanthocephalan parasite have shown a decrease in host defence capacities. Cornet et al. (2009) measured a reduction of the prophenoloxidase system as well as of haemocyte concentration, 2 major parameters of crustacean immunity, in G. pulex infected by 1 of the 3 following acanthocephalan parasites: Pomphorhynchus laevis, Pomphorhynchus tereticollis and P. minutus. Sures and Radszuweit (2007) also demonstrated that the cystacanth stage of $P$. minutus prevented the synthesis of heat shock protein 70 in $G$. roeseli subjected to a thermal disturbance or palladium exposure. Additionally, a decrease in defence capacities was also observed in other host-parasite relationships. For example, digenean-infected cockles exposed to cadmium displayed lower metallothionein concentrations than uninfected ones (Baudrimont et al. 2006). According to our results, malondialdehyde (MDA), a product of lipid peroxidation reflecting cellular damage, was weaker in infected individuals. Thus, on the one hand the drop in antitoxic defences in infected gammarids suggests a higher sensitivity to stress conditions but, on the other hand, a decrease in MDA levels suggests a protective effect of the parasite on its host. Inside the host, the parasite has to escape from/survive the host's defence system and consequently weaken it, but if the host's antitoxic defence capacities are too low, the survival of the hostparasite pair can be compromised in stressful conditions. A compensation system may occur to counterbalance the weakening of the host's defence system.

Sures and Radszuweit (2007) demonstrated that $P$. minutus cystacanths of $G$. roeseli exposed to palladium had accumulated 10 times as much metal as their hosts. In a previous study, we demonstrated that $P$. minutus cystacanths could accumulate cadmium (Gismondi et al. unpublished data). So, we can hypothesize that if the parasite can accumulate toxic contaminants, toxicity to the host may be reduced. Consequently, the host may need lower antitoxic defences, and the parasite may protect it during environmental stress. However, this hypothesis remains to be tested.
The present study confirms that an acanthocephalan parasite reduces the energy reserves of its host. We also observed lower defence capacities in infected individuals as compared to uninfected ones, in the absence of stressors. We cannot rule out that parasites may infect organisms with a low defence system but the information provided by glutathione concentrations and MDA levels altogether suggests that the physiological modifications we observed resulted from infection, but did not cause it. To go further, the consequences of the modifications we observed in $P$. minutus-infected gammarids on fitness will have to be assessed in a contamination context.

\section{ACKNOWLEDGMENTS}

This study was supported by the French Ministry of Education and Research (Ministère de l'Enseignement Supérieur et de la Recherche), which we sincerely thank here. The present work is part of the research program EC2CO (Ecosphère Continentale et Côtière). We are grateful to Annie Buchwalter for improving the English text and we wish to thank the two anonymous reviewers for their helpful comments on a previous draft of this paper.

\section{REFERENCES}

Bakker, T. C., Mazzi, D. and Zala, S. (1997). Parasite-induced changes in behavior and color make Gammarus pulex more prone to fish predation. Ecology 78, 1098-1104.

Baldauf, S. A., Thünken, T., Frommen, J. G., Bakker, T.C. M., Heupel, O. and Kullmann, H. (2007). Infection with an acanthocephalan manipulates an amphipod's reaction to a fish predator's odours. International fournal for Parasitology 37, 61-65. doi:10.1016/j.ijpara. 2006.09.003.

Barnard, J. L. and Barnard, C. M. (1983). Freshwater Amphipoda of the World I \& II. Hayfield Associates, Mt. Vernon, VA, USA.

Barrett, J. and Butterworth, P. E. (1968). The carotenoids of Polymorphus minutus (Acanthocephala) and its intermediate host, Gammarus Pulex. Comparative Biochemistry and Physiology 27, 575-581. doi:10.1016/ 0010-406X(68)90254-5.

Baudrimont, M., De Montaudouin, X. and Palvadeau, A. (2006). Impact of digenean parasite infection on metallothionein synthesis by the cockle (Cerastoderma edule): A multivariate field monitoring. Marine Pollution Bulletin 52, 494-502. doi:10.1016/j.marpolbul.2005.09.035.

Bauer, A., Trouvé, S., Grégoire, A., Bollache, L. and Cézilly, F. (2000). Differential influence of Pomphorhynchus laevis (Acanthocephala) on the behaviour of native and invader gammarid species. International Yournal for Parasitology 30, 1453-1457. doi:10.1016/S0020-7519(00)00138-7.

Bauer, A., Haine, E. R., Perrot-Minnot, M. J. and Rigaud, T. (2005). The acanthocephalan parasite Polymorphus minutus alters the geotactic and clinging behaviours of two sympatric amphipod hosts: the native Gammarus pulex and the invasive Gammarus roeseli. Fournal of Zoology 267, 39-43. doi: 10.1017/S0952836905007223.

Behrens, W. and Madère, R. (1991). Malonaldehyde determination in tissues and biological fluids by ion-pairing high-performance liquid chromatography. Lipids 26, 232-236. doi: 10.1007/BF02543977.

Beisel, J. N. and Médoc, V. (2010). Bird and amphipod parasites illustrate a gradient from adaptation to exaptation in complex life cycle. Ethology Ecology and Evolution 22, 265-270. doi: 10.1080/ 03949370.2010 .502321 .

Bollache, L., Rigaud, T. and Cézilly, F. (2002). Effects of two acanthocephalan parasites on the fecundity and pairing status of female Gammarus pulex (Crustacea: Amphipoda). Fournal of Invertebrate Pathology 79, 102-110. doi:10.1016/S0022-2011(02)00027-7.

Bradford, M. M. (1976). A rapid and sensitive method for the quantitation of microgram quantities of protein utilizing the principle of protein-dye binding. Analytical Biochemistry 72, 248-254. doi:10.1016/0003-2697(76) 90527-3. 
Canesi, L., Viarengo, A., Leonzio, C., Filippelli, M. and Gallo, G. (1999). Heavy metals and glutathione metabolism in mussel tissues. Aquatic Toxicology 46, 67-76. doi:10.1016/S0166-445X(98)00116-7.

Cargill, A. S., Cummin, K. W., Hanson, B. J. and Lowry, R. R. (1985). The role of lipids as feeding stimulants for shredding aquatic insects. Freshwater Biology 15, 455-464. doi: 10.1111/j.1365-2427.1985.tb00215.x. Cézilly, F., Gregoire, A. and Bertin, A. (2000). Conflict between cooccurring manipulative parasites? An experimental study of the joint influence of two acanthocephalan parasites on the behaviour of Gammarus pulex. Parasitology 120, 625-630.

Cézilly, F. and Perrot-Minnot, M. J. (2005). Studying adaptive changes in the behaviour of infected hosts: a long and winding road. Behavioural Processes 68, 223-228. doi:10.1016/j.beproc.2004.08.013.

Cézilly, F., Thomas, F., Médoc, V. and Perrot-Minnot, M. J. (2010). Host-manipulation by parasites with complex life cycles: adaptive or not? Trends in Parasitology 26, 311-317. doi: 10.1016/j.pt.2010.03.009.

Cornet, S., Franceschi, N., Bauer, A., Rigaud, T. and Moret, Y. (2009). Immune depression induced by acanthocephalan parasites in their intermediate crustacean host: Consequences for the risk of super-infection and links with host behavioural manipulation. International fournal for Parasitology 39, 221-229. doi:10.1016/j.ijpara.2008.06.007.

Correia, A. D., Livingstone, D. R. and Costa, M. H. (2002). Effects of water-borne copper on metallothionein and lipid peroxidation in the marine amphipod Gammarus locusta. Marine Environmental Research 54, 357-360. doi:10.1016/S0141-1136(02)00114-9.

Crompton, D.W. T. and Nickol, B. B. (1985). Biology of the Acanthocephala, Cambridge University Press, Cambridge, UK.

Dezfuli, B. S., Giari, L., Arrighi, S., Domeneghini, C. and Bosi, G. (2003). Influence of enteric helminths on the distribution of intestinal endocrine cells belonging to the diffuse endocrine system in brown trout, Salmo trutta L. Journal of Fish Diseases 26, 155-166. doi: 10.1046/j.13652761.2003.00446.x.

Dick, J. T. A., Armstrong, M., Clarke, H.C., Farnsworth, K. D., Hatcher, M. J., Ennis, M., Kelly, A. and Dunn, A. M. (2010). Parasitism may enhance rather than reduce the predatory impact of an invader. Biology Letters 6, 636-638. doi: 10.1098/rsbl.2010.0171.

Doyotte, A., Cossu, C., Jacquin, M. C., Babut, M. and Vasseur, P. (1997). Antioxidant enzymes, glutathione and lipid peroxidation as relevant biomarkers of experimental or field exposure in the gills and the digestive gland of the freshwater bivalve Unio tumidus. Aquatic Toxicology 39, 93-110. doi:10.1016/S0166-445X(97)00024-6.

Griffith, O. W. (1999). Biologic and pharmacologic regulation of mammalian glutathione synthesis. Free Radical Biology and Medicine 27, 922-935. doi:10.1016/S0891-5849(99)00176-8.

Jazdzewski, K. (1980). Range extensions of some gammaridean species in european inland waters caused by human activity. Crustaceana 6, 84-107. Kennedy, C. R. (2006). Ecology of the Acanthocephala. Cambridge University Press, Cambridge, UK.

Lafferty, K. D. (1999). The evolution of trophic transmission. Parasitology 15, 111-115. doi:10.1016/S0169-4758(99)01397-6.

Lagrue, C., Kaldonski, N., Perrot-Minnot, M. J., Motreuil, S. and Bollache, L. (2007). Modification of hosts' behavior by a parasite: field evidence for adaptive manipulation. Ecology 88, 2839-2847. doi:10.1890/062105.1.

Leroy, P., Nicolas, A., Thioudellet, C., Oster, T., Wellman, M. and Siest, G. (1993). Rapid liquid chromatographic assay of glutathione in cultured cells. Biomedical Chromatography 7, 86-89. doi:10.1002/ bmc. 1130070208 .

Mantiri, D. M.H., Negre-Sadargues, G., Charmantier, G., Trilles, J. P., Milicua, J. C. G. and Castillo, R. (1996). Nature and metabolism of carotenoid pigments during the embryogenesis of the European Lobster Homarus gammarus (Linne, 1758). Comparative Biochemistry and Physiology Part A: Physiology 115, 237-241. doi:10.1016/0300-9629(96)00054-0.

Maynard, B. J., Wellnitz, T.A., Zanini, N., Wright, W. G. and Dezfuli, B. S. (1998). Parasite-altered behavior in a crustacean intermediate host : field and laboratory studies. Fournal of Parasitology 84, 1102-1106.

McCahon, C. P., Maund, S. J. and Poulton, M. J. (1991). The effect of the acanthocephalan parasite (Pomphorhynchus laevis) on the drift of its intermediate host (Gammarus pulex). Freshwater Biology 25, 507-513. doi: 10.1111/j.1365-2427.1991.tb01393.x.

Médoc, V., Bollache, L. and Beisel, J. N. (2006). Host manipulation of a freshwater crustacean (Gammarus roeseli) by an acanthocephalan parasite (Polymorphus minutus) in a biological invasion context. International Fournal for Parasitology 36, 1351-1358. doi:10.1016/j. ijpara.2006.07.001

Médoc, V., Rigaud, T., Bollache, L. and Beisel, J. N. (2009). A manipulative parasite increasing an antipredator response decreases its vulnerability to a nonhost predator. Animal Behaviour 77, 1235-1241. doi:10.1016/j.anbehav.2009.01.029.

Médoc, V. and Beisel, J. N. (2009). Field evidence for non-host predator avoidance in a manipulated amphipod. Naturwissenschaften 96, 513-523. doi: 10.1007/s00114-008-0503-8.

Médoc, V., Piscart, C., Maazouzi, C., Simon, L. and Beisel, J.-N. (2011). Parasite-Induced Changes in the Diet of a Freshwater Amphipod: Field and Laboratory Evidence. Parasitology 138, 537-546. doi: 10.1017/ S0031182010001617.

Neuparth, T., Correia, A. D., Costa, F. O., Lima, G. and Costa, M. H. (2005). Multi-level assessment of chronic toxicity of estuarine sediments with the amphipod Gammarus locusta: I. Biochemical endpoints. Marine Environmental Research 60, 69-91. doi:10.1016/j.marenvres.2004.08.006.

Neves, C.A., Sampedro, Pastor, M.P., Nery, L.E.M. and Santos, E. A. (2004). Effects of the parasite Probopyrus ringueleti (Isopoda) on glucose, glycogen and lipid concentration in starved Palaemonetes argentinus (Decapoda). Diseases of Aquatic Organisms 58, 209-213.

Parmentier, C., Leroy, P., Wellman, M. and Nicolas, A. (1998) Determination of cellular thiols and glutathione-related enzyme activities: versatility of high-performance liquid chromatography-spectrofluorimetric detection. Fournal of Chromatography B: Biomedical Sciences and Applications 719, 37-46. doi:10.1016/S0378-4347(98)00414-9.

Perrot-Minnot, M. J. (2004). Larval morphology, genetic divergence, and contrasting levels of host manipulation between forms of Pomphorhynchus laevis (Acanthocephala). International Fournal for Parasitology 34, 45-54. doi:10.1016/j.ijpara.2003.10.005.

Perrot-Minnot, M. J., Kaldonski, N. and Cézilly, F. (2007). Increased susceptibility to predation and altered anti-predator behaviour in an acanthocephalan-infected amphipod. International fournal for Parasitology 37, 645-651. doi:10.1016/j.ijpara.2006.12.005.

Plaistow, S. J., Troussard, J. P. and Cézilly, F. (2001). The effect of the acanthocephalan parasite Pomphorhynchus laevis on the lipid and glycogen content of its intermediate host Gammarus pulex. International fournal for Parasitology 31, 346-351. doi:10.1016/S0020-7519(01)00115-1.

Poulin, R. (1995). "Adaptive" changes in the behaviour of parasitized animals: A critical review. International fournal for Parasitology 25, 1371-1383. doi:10.1016/0020-7519(95)00100-X.

Sparkes, T. C., Keogh, D. P. and Pary, R. A. (1996). Energetic costs of mate guarding behavior in male stream-dwelling isopods. Oecologia 106, 166-171. doi: 10.1007/BF00328595.

Sroda, S. and Cossu-Leguille, C. (2011a). Seasonal variability of antioxidant biomarkers and energy reserves in the freshwater gammarid Gammarus roeseli. Chemosphere 83, 538-544. doi:10.1016/j.chemosphere. 2010.12.023.

Sroda, S. and Cossu-Leguille, C. $(2011 b)$. Effects of sublethal copper exposure on two gammarid species: which is the best competitor? Ecotoxicology 20, 264-273. doi: 10.1007/s10646-010-0578-9.

Stentiford, G. D., Neil, D. M. and Coombs, G. H. (2001). Development and application of an immunoassay diagnostic technique for studying Hematodinium infections in Nephrops norvegicus populations. Diseases of Aquatic Organisms 46, 223-229.

Sures, B., Dezfuli, B. S. and Krug, H. F. (2003). The intestinal parasite Pomphorhynchus laevis (Acanthocephala) interferes with the uptake and accumulation of lead $\left({ }^{210} \mathrm{~Pb}\right)$ in its fish host chub (Leuciscus cephalus). International Fournal for Parasitology 33, 1617-1622. doi:10.1016/S00207519(03)00251-0.

Sures, B. and Siddall, R. (1999). Pomphorhynchus laevis: The intestinal Acanthocephalan as a lead sink for its fish host, chub (Leuciscus cephalus). Experimental Parasitology 93, 66-72. doi:10.1006/expr.1999.4437.

Sures, B., Taraschewski, H. and Jackwerth, E. (1994). Lead accumulation in Pomphorhynchus laevis and its host. Fournal of Parasitology 80, 355-357. doi: 10.2307/3283403.

Sures, B. and Radszuweit, H. (2007). Pollution induced heat shock protein expression in the amphipod Gammarus roeseli is affected by larvae of Polymorphus minutus (Acanthocephala). Fournal of Helminthology 81, 191-197. doi: 10.1017/S0022149X07751465.

Sutcliffe, D.W. (1993). Reproduction in Gammarus (Crustacea Amphipoda): female strategies. Freshwater Forum 3, 26-65.

Taraschewski, H. (2000). Host-parasite interactions in acanthocephalan: a morphological approach. Advances in Parasitology 46, 1-179.

Vasseur, P. and Leguille, C. (2004). Defense systems of benthic invertebrates in response to environmental stressors. Environmental Toxicology 19, 433-436. doi: 10.1002/tox.20024.

Yan, T., Teo, L. H. and Sin, Y. M. (1997). Effects of mercury and lead on tissue glutathione of the green mussel, Perna viridis L. Bulletin of Environmental Contamination and Toxicology 58, 845-850. doi: 10.1007/ s001289900411. 